\title{
TRANS OBTURATOR TAPE FOR FEMALE URINARY STRESS INCONTINENCE TREATMENT: A CONTRIBUTION TO ITS EMPLOYMENT IN CLINICAL PRACTICE
}

\author{
P. Farnelli, A. Parodi \\ Operative Unit of Gynaecology and Obstetrics \\ "Infermi " Hospital - Rimini (Italy) \\ Direttore f.f. Dr. P. Farnelli
}

Keywords:

Monarc - TOT - mesh - obturator - stress urinary incontinence

\begin{abstract}
The TOT procedure is considered one of the most useful techniques for treating female SUI. The hypothesis of this study is to confirm its real efficacy in daily practice. The material of the study is a group of 55 women affected by SUI in which this technique was performed. After a preoperative standardized assessment the patients underwent an early postoperative evaluation and a six month and one year follow up looking for surgical complications and evaluating the efficacy of the procedure using QL questionnaires. The results show that there were no major intra or post operative complications. At the six month and one year follow up $95.5 \%$ of the patients were fully satisfied while the remaining $4.5 \%$ stated they had improved. The authors can confirm that TOT is a very safe and successful technique for treating SUI and can be widely employed in daily practice.
\end{abstract}

\section{SUMMARY}

In this work paper the Authors provide a contribution to confirm the usefulness of the TOT technique in the treatment of female urinary stress incontinence. 


\section{INTRODUCTION}

Urinary incontinence is a prevalent condition that impacts many women's lives. Stress urinary incontinence (SUI), urine loss associated with exertion, typically has its onset during the reproductive years, whereas urge incontinence, urine loss associated with urgency, more frequently affects postmenopausal women. Mixed incontinence, a combination of stress and urge incontinence, affects up to $30 \%$ of incontinent women [1] Physiotherapy, including pelvic floor exercises, biofeedback, and functional electrical stimulation, centre on improving pelvic floor neuromuscular function, thus improving bladder and urethral function [2]. Current pharmacologic treatments focus primarily on urge incontinence, anticholinergics being the mainstays of therapy. Local oestrogen therapy may improve urethral and bladder function if a woman's incontinence is associated with urogenital atrophy. Surgery is primarily reserved for management of severe SUI [1]. Minimally invasive sling procedures have replaced the Burch colposuspension as the most common surgery performed for SUI, and appear to have similar success rates.

The current method of treating female urinary incontinence is based on the placement of a sling: a tension-free sub urethral vaginal tape, using a retropubic or transobturator approach. During the last 4 years the use of a polypropylene tape placed tension free under the mid urethra seems to have become the gold standard therapy for SUI associated to urethral hypermobility [3] [4] [5] [6] [7].

Pathophysiological concepts and theories on clinical staging have changed in recent years. The importance of pressure transmission and hammock-like support has been complemented by the so-called 'integral' theory. An analysis of the available literature shows that the new sling procedures provide a new reference point in time because they not only show good medium-term results, but they are also minimally invasive with quick post-operative recovery [7].

During 2004 a long retrospective study performed a review of the international literature on Medline between 1968 and 2004, on surgical techniques for the treatment of female stress urinary incontinence [6]. The TVT procedure is widely used for surgical treatment of female SUI. The transobturator approach, which allows a reduction of morbidity, was the choice for more than $25 \%$ of the physicians in 2003.

Since then the technique of the tension free polypropylene tape positioned under the mid urethra has been employed more and more. Maybe one of the advantages determining the effectiveness of this technique is represented by the characteristics of the monofilament tape made of polypropylene, which is rarely knitted and highly elastic. Giant multinucleated cells forming granulation tissue were found near the monofilaments. Moreover, this granulation tissue has many new blood vessels and much collagenous fibrous tissue so it can create a real new sub urethral support [8]. 
The physicians can follow two routes while placing the tape: TVT or TOT [9] [3] [10] [11] [5] [6] [12] [13].

The wide use of retropubic TVT seemed to be associated with various complications, operative (bladder perforation, retropubic haematoma), early postoperative (urinary retention) and late postoperative complications (urge incontinence, vaginal protrusion of the tape) [14] [15]. To avoid these complications, alternative procedures have been developed and the continence rates obtained with these new routes are quite similar to those after classic TVT. In the transobturator technique (TOT) described by Delorme and colleagues in 2001, the tape is inserted through the obturator foramen from the outside to the inside and is positioned without tension under the urethra [16]. Subsequent studies demonstrated the efficacy of this procedure in women affected by genuine stress urinary incontinence particularly when urethral hypermobility is associated and even when other procedures, like vaginal hysterectomy or pelvic floor reconstructive surgery are associated [3] [13] [17] [18] [19] [20].

In this paper the authors report their contribution in terms of results of the safety and efficacy of this new mini invasive technique, used to treat female urinary incontinence with the transobturator placement of a tension free polypropylene tape.

\section{MATERIALS AND METHODS}

From June 2005 to December 2007 in the Operative Unit of Obstetrics and Gynaecology - Gynaecology Section in the Infermi Hospital - ASL Rimini (Italy) the authors enrolled 55 women suffering from SUI associated with urethral hypermobility, to be surgically treated.

In all the patients the preoperative assessment was standardized, and consisted of a gynaecologic pelvic examination, pad test and stress test (filling bladder with $300 \mathrm{ml}$ of saline solution), Q tip test and Bonney test, and QL assessment using Incontinence Impact Questionnaire Short Form (IIQ-7) questionnaires [21] and the King's Health questionnaire to value the quality of life [22] according to the IUGA recommendations [23]. In the cases in which urge incontinence or sphincteral insufficiency was suspected, a urodynamic workup was performed.

Four patients underwent previous surgical procedure for incontinence (3 Kelly and 1 Burch). Only four patients reported previous major gynaecological surgery. The ean age was 58.68 years (range 36-75).

In 43 of the women investigated, genital prolapse in various degrees was associated (Group A). The patients included in this group underwent pelvic floor reconstruction procedures (PFR group).

In 12 of them there was no pelvic floor defect but urethral hypermobility was present (Group B).

Patients with associated urge incontinence, evidenced by a urody- 
namic workup, were excluded from the studied groups.

All 55 patients underwent an out in TOT procedure following the classic Delorme technique; the device used was a monofilament polypropylene tension free tape inserted under the mid urethra using two specially curved needles (Monarc System AMS, Minnesota USA) passed through the obturator foramens.

All the patients of both groups were operated on by two experienced surgeons under spinal or general anaesthesia.

Cystoscopy was only performed if there was suspicion of a bladder/urethral lesion. There was suspicion when contact of the index finger with the needle was lost during the placement.

An intravenous prophylactic $2 \mathrm{~g}$ dose of amoxicillin-clavulanic acid was administered.

In 43 patients $(78.1 \%$ ) (group $\mathrm{A}$ or the PFR group), a pelvic floor reconstruction was needed, with one or more techniques: 32 cystocele repairs, 28 rectocele repairs. Vaginal hysterectomy was performed in 39 patients of this group. Four women were previously hysterectomised. The remaining 12 patients (21.9\%) (group B) who did not need pelvic floor reconstruction underwent only the TOT procedure (Table I). In all the patients the bladder catheter was removed 2 days after surgical procedure.

Intraoperative and early postoperative complications were evaluated. All incidents starting from the end of the operative procedure until dis- charge from hospital were considered early postoperative complications..The comparison of acute postoperative obstructive symptoms was considered when bladder catheterization, necessary due to post-operative urinary retention, was prolonged for more than 3 days. Significant blood loss was considered when patients needed transfusions or when $\mathrm{Hb}$ levels decreased by more than $2 \mathrm{~g} / \mathrm{dl}$. Urinary infections were also considered by a urine culture after removal of the catheter.

Before being discharged from hospital all the 55 patients underwent a post-operative clinical evaluation of a urine sample, a post-voiding residual assessment performed by pelvic ultrasonography, PAD and stress test (full bladder cough test). The patients were discharged from the hospital when in a good clinical condition and when the post-voiding residual assessment indicated a urinary retention $<50 / 100 \mathrm{ml}$.

A six month and one year outcome was evaluated with a clinical examination (looking for erosions determined by the tape or comparison of cystocele or vaginal vault prolapse or any anatomical complications), QL assessment questionnaires like during the preoperative preparation (asking for a subjective complete, partial or no patient satisfaction), measurement of post-voiding urinary retention performed by pelvic ultrasonography and catheterization (a urinary retention of 50/100 $\mathrm{ml}$ was considered insignificant), and $\mathrm{PAD} /$ stress test (full bladder cough test to evaluate urinary continence). 
Table I - Groups of patients submitted to the TOT procedure

\begin{tabular}{cc}
\hline $\begin{array}{c}\text { Group A: pelvic floor } \\
\text { reconstruction +TOT group }\end{array}$ & $\begin{array}{c}\text { Group B: only TOT } \\
\text { procedure }\end{array}$ \\
\hline 32 submitted to cystocele repair & \\
\hline 28 submitted to rectocele repair, & \\
\hline 39 submitted to vaginal hysterectomy & $\mathbf{1 2}$ patients $(\mathbf{2 1 . 9 \% )}$ \\
\hline Total $\mathbf{4 3}$ patients (78.1\%)
\end{tabular}

Table II - Intraoperative, early postoperative, six month and one year follow up

\begin{tabular}{lccc}
\hline & $\begin{array}{c}\text { Intraoperative/early } \\
\text { postoperative follow up }\end{array}$ & $\begin{array}{c}\text { Six month } \\
\text { follow up }\end{array}$ & $\begin{array}{c}\text { One year follow } \\
\text { up }\end{array}$ \\
\hline Group A & 43 cases & 35 cases & 33 cases \\
\hline Group B & 12 cases & 11 cases & 10 cases \\
\hline Total & $\mathbf{5 5}$ cases & $\mathbf{4 6}$ cases & $\mathbf{4 3}$ cases \\
\hline
\end{tabular}

\section{RESULTS}

Evaluation of the surgical outcome was possible for the entire group ( 55 patients) regarding the intraoperative and the early postoperative period. A six month follow up was performed in 46 patients; the one year follow up was possible in 43 women. Globally in the one year follow up 12 cases were missed (Table II).

In the whole group no death and no severe intra or postoperative severe complications occurred.

The intraoperative and early post operative outcome of the 55 treated cases is shown in Table III.

As shown in this table mean hos- pitalisation after the operation was about 3.6 days (range 2-5 days) for group A (patients who underwent pelvic floor reconstruction associated with the TOT procedure) and 1.5 days (range 1-3) for group B (patients who only underwent the TOT procedure). The mean surgical time was 80 minutes (range 60-120) in group A and 15 minutes (range 7-20) in group B. There was no need to perform an intraoperative blood transfusion. In only 5 cases, out of the entire group, was cystoscopy performed, because of a doubt regarding bladder or urethral lesions. In any case no bladder perforation or urethral, vascular (haematoma, severe bleeding) or 
Table III - 55 patients' intraoperative and early postoperative outcome

\begin{tabular}{|c|c|c|c|}
\hline & $\begin{array}{l}\text { Group A } \\
\text { (PFR) }\end{array}$ & $\begin{array}{l}\text { Group B } \\
\text { (TOT only) }\end{array}$ & $\begin{array}{l}\text { Whole } \\
\text { group }\end{array}$ \\
\hline N. of Patients & 43 & 12 & 55 \\
\hline Mean Hosp. Stay & 3.6 days.( range $2-5)$ & $1,5$ (range $1-3)$ & \\
\hline Mean Surgical Time & $80 \mathrm{~min}$ (range 60-120) & $15 \min ($ range $7-20)$ & \\
\hline Need for Cystoscopy & 3 cases & 2 cases & $5(9 \%)$ \\
\hline Intraop. transfusion & 0 & 0 & \\
\hline Bladder Injuries & 0 & 0 & \\
\hline Urethral Injuries & 0 & 0 & \\
\hline Vascular Injuries & 0 & 0 & \\
\hline Neurological injuries & 0 & 0 & \\
\hline Postop. Urinary retention & $6(13 \%)$ & $2(16 \%)$ & $8(14,5 \%)$ \\
\hline Postop. Transfusions & 4 & 0 & $4(7.2 \%)$ \\
\hline $\mathrm{Hb}$ loss $>2$ & 10 & 1 & $11(20 \%)$ \\
\hline Positive urine cultures & $11(25 \%)$ & $4(33 \%)$ & $15(27.2 \%)$ \\
\hline Early Positive pad/stress & $7(16 \%)$ & 1 & $8(14.5 \%)$ \\
\hline
\end{tabular}

neurological injuries occurred. Acute postoperative urinary retention was observed in 6 cases among group A and in 2 cases of group B. The need to perform postoperative blood transfusions was only observed in 4 cases in group A. Haemoglobin loss $>2$ was observed in 10 cases in group A and in only one case among group B. Early postoperative urinary infections were identified in 15 cases $(27,5 \%)$. Urinary loss identified by a positive $\mathrm{pad} /$ stress test immediately before hospital discharging was demonstrated in 8 cases of the entire group (on- ly one case in group B). None of the patients needed to remove the tape in the early post operative period.

At six months after surgical procedure follow up was possible only in 46 cases. The outcome after this period is shown in Table IV.

As shown in the table no symptoms of erosion occurred in the 6 months after the operation. Surgical removal or section of the tape was not necessary in any of the $46 \mathrm{pa}$ tients. The TOT procedure did not provoke anatomical complications in any of the patients. In $91.6 \%$ of the 
Table IV - 46 patients 6 month follow up

\begin{tabular}{lccc}
\hline & $\begin{array}{c}\text { Group A } \\
\text { (PFR) }\end{array}$ & $\begin{array}{c}\text { Group B } \\
\text { (TOT only) }\end{array}$ & $\begin{array}{c}\text { Whole } \\
\text { group }\end{array}$ \\
\hline N. of patients & 34 & 12 & 46 \\
\hline Symptoms of erosions & 0 & 0 & 0 \\
\hline $\begin{array}{l}\text { Other Anatomical } \\
\text { complications }\end{array}$ & $\begin{array}{c}\text { c cases of vaginal } \\
\text { posterior stenosis }\end{array}$ & 0 & 2 \\
\hline Subjective complete satisfaction & $30(88 \%)$ & $11(91.6 \%)$ & $41((89.1 \%)$ \\
\hline Subjective partial satisfaction & $4(11.7 \%)$ & 0 & $4(8.6 \%)$ \\
\hline No subjective satisfaction & 0 & 1 & $1(2.1 \%)$ \\
\hline Post voiding urinary retention & 0 & 0 & 0 \\
\hline Positive pad/stress test & 0 & 1 & $1(2.1 \%)$ \\
\hline
\end{tabular}

patients in group B there was complete subjective satisfaction after 6 months from the surgical procedure; $88 \%$ in group $\mathrm{A}$. In the whole group a high percentage of women (89.1\%) referred complete subjective satisfaction; partial satisfaction was only reported in $8.6 \%$ of the women. In only one case of group $\mathrm{B}$ was there no change in their subjective sensations (2.1\% of the entire group). And only in this case was there a positive $\mathrm{pad} /$ stress test. In none of the $46 \mathrm{pa}$ tients was post voiding urinary retention demonstrated.

One year follow up was carried out in 43 cases. The results are reported in Table $\mathbf{~}$.

As shown in the table none of the patients suffered from vaginal erosion by the tape. In only one case did we notice skin erosion at the point of introduction of the needles, maybe due to an incorrect section of the tape at this level. Complete subjective satisfaction associated with a negative $\mathrm{pad} /$ stress test was reported in 95.5\% of the cases studied. The remaining $4.5 \%$ of the patients showed a positive $\mathrm{PAD} /$ stress test but in any case they referred partial subjective satisfaction.

\section{DISCUSSION}

The primary aim of this study was to determine if the employment of the out-in TOT technique is really useful in daily clinical practice regarding the treatment of the female urinary stress incontinence. The first point to mention is the very low percentage of intraoperative and early postoperative complications in the group of patients that underwent the 
Table V - 43 patients one year follow up

\begin{tabular}{lccc}
\hline & $\begin{array}{c}\text { Group A } \\
\text { (PFR) }\end{array}$ & $\begin{array}{c}\text { Group B } \\
\text { (TOT only) }\end{array}$ & $\begin{array}{c}\text { Whole } \\
\text { group }\end{array}$ \\
\hline N. of patients & 32 & 11 & 43 \\
\hline Symptoms of erosions & 0 & 0 & 0 \\
\hline Other Anatomical complications & 1 case of & 0 & 1 \\
\hline Subjective complete satisfaction & 30 & 11 & $41(95.5 \%)$ \\
\hline Subjective partial satisfaction & 2 & 0 & $2(4.5 \%)$ \\
\hline No subjective satisfaction & 0 & 0 & 0 \\
\hline Post voiding urinary retention & 0 & 0 & 0 \\
\hline Positive pad/stress test & 2 & $2(4.5 \%)$ \\
\hline
\end{tabular}

TOT procedure. No major complications occurred in the intraoperative period or in the early post operative period. No difference was noted regarding this problem between the group that underwent only the TOT procedure and the group in which pelvic floor reconstruction procedures were associated. In only a few cases was cystoscopy needed in the doubt of urethral or bladder lesions, confirming that the out-in TOT procedure is a relatively simply technique with a very short learning period. In the group of patients who underwent only the TOT procedure, hospitalisation was about 1.5 days according to the international data ([24] [25] [26]), which leads one to consider the TOT technique a one day surgery procedure. The employment of TOT did not prolong the patients' stay in hospital when associated to pelvic floor reconstruction, such as vaginal hys- terectomy or the correction of cystocele and rectocele. The most frequent complication was early post operative urinary retention that we observed in $14.5 \%$ of the patients treated. The same percentage resulted for the cases in which urinary incontinence was not adequately corrected immediately after the operation. In fact in $14.5 \%$ of the cases the $\mathrm{pad} / \mathrm{stress}$ test was positive at the time of hospital discharge. A urinary infection was another early complication we observed in the early post operative period; in any case the infections were easily treated with appropriate antibiotic therapy after a urine culture. Significant blood loss was observed only when TOT was associated with pelvic floor reconstruction procedures, due to the characteristics of these techniques and not to the TOT, which can be considered really minimally invasive. 
In the six months and one year follow up no symptoms of erosion or other anatomical complications were observed except for two cases of vaginal stenosis due to a posterior wall retraction in patients who underwent a rectocele correction.

There was a high percent of patients with complete subjective satisfaction $(89.1 \%)$ at 6 months, which was even higher (95.5\%) after one year from the operation. In only two cases was the PAD/stress test still positive after one year but in any case these two patients stated that their condition had improved. So the TOT procedure can be considered completely successful in $95.5 \%$ of the cases and sufficiently successful for nearly $100 \%$ of the patients treated.
Concluding the analysis of our data we can say that the out-in TOT procedure is a very safe technique, which can be used regularly in daily clinical practice in order to treat female SUI. In our experience, in accordance with the international literature, it seems less dangerous and easier to learn than the retro pubic way [24] [25] [26]. On the other hand the high percentage of successfully treated cases - even in the patients who need other vaginal surgical procedures - confirms that it can be widely employed to treat urinary stress incontinence. We think that, at this time of the evolution of urogynaecology, TOT should be part of the technical skills of every surgeon performing pelvic floor reconstructive surgery.

\section{REFERENCES}

1 - DAVILA G.W., GUERETTE N. :

(2004) Current treatment options for female urinary incontinence - a review. Int J Fertil Womens Med. May-Jun; 49(3):102-12.

2 - RICHTER H.E., BURGIO K.L., GOODE P.S., BORELLO-FRANCE D., BRADLEY C.S., BRUBAKER L., HANDA V.L., FINE P.M., VISCO A.G., ZYCZYNSKI H.M., WEI J.T., WEBER A.M. :

(2007) Non-surgical management of stress urinary incontinence:

ambulatory treatments for leakage associated with stress.

Clin Trials.; 4(1):92-101.

3 - COSTA P., GRISE P., DROUPY S., MONNEINS F., ASSENMACHER C., BALLANGER P., HERMIEU J.F., DELMAS V., BOCCON-GIBOD L., ORTUNO C. : (2004) Surgical treatment of female stress urinary incontinence with a transobturator-tape (T.O.T.) Uratape: short term results of a prospective multicentric study.

Eur Urol. Jul;46(1):102-6; 
4 - SPINOSA J.P., DUBUIS P.Y. :

(2005) Suburethral sling inserted by the transobturator route in the treatment of female stress urinary incontinence: preliminary results in 117 cases.

Eur J Obstet Gynecol Reprod Biol. Dec 1; 123(2):212-7.

5 - ARGIROVI R., LIKI LADEVI I., BOSKOVI V., BERISAVAC M., MILENKOVI V., KADIJA S. :

(2006) Novel surgical procedure for the treatment of female stress urinary incontinence by using transobturator vaginal tape.

Vojnosanit Pregl. Aug; 63(8):721-4.

6 - DE TAYRAC R., MADELENAT P. :

(2004) Evolution of surgical routes in female stress urinary incontinence.

Gynecol Obstet Fertil. Dec; 32(12):1031-8.

7 - BEMELMANS B.L., CHAPPLE C.R. :

(2003) Are slings now the gold standard treatment for the management of female urinary stress incontinence and if so which technique?

Curr Opin Urol. Jul; 13(4):301-7

8 - RECHBERGER T., WrÓBEL A., ADAMIAK A., SKOMRA D., KOROBOWiCZ E., TOMASZEWSKI J., CZUCZWAR M., SKORUPSKI P. :

(2003)Tissue reaction to polypropylene mono-or multi-filament tapes used in surgical techniques of stress urinary incontinence treatment.

Ginekol Pol. Sep; 74(9):1008-13.

9 - DE LEVAL J., WALTREGNY D. :

(2005) New surgical technique for treatment of stress urinary incontinence TVT-Obturator: new developments and results.

Surg Technol Int.; 14:212-21.

10 - WALTREGNY D., REUL O., MATHANTU B., GASPAR Y., BONNET P., DE LEVAL J. :

(2006) Inside out transobturator vaginal tape for the treatment of female stress urinary incontinence: interim results of a prospective study after a 1year minimum follow up.

J Urol. Jun; 175(6):2191-5.

11 - ANKARDAL M., HEIWALL B., LAUSTEN-THOMSEN N., CARNELID J., MILSOM I. : (2006) Short-and long-term results of the tension-free vaginal tape procedure in the treatment of female urinary incontinence.

Acta Obstet Gynecol Scand.; 85(8):986-92. 
12 - NAVALÓN VERDEJO P., ZARAGOZÁ FERNÁNDEZ C., ORDOÑO DOMÍNGUEZ F., SÁNCHEZ BALLESTER F., JUAN ESCUDERO J., FABUEL DELTORO M., DE LA TORRE ABRIL L., LÓPEZ ALCINA E. : (2005) Outpatient surgical treatment of female stress urinary incontinence. Arch Esp Urol. Nov;58(9):915-22;

13 - GUNNEMANN A., HELEIS W., POHL J., PALIAKOUDIS I., THIEL R. : (2004)The transobturator tape (TOT). A minimally-invasive procedure for the treatment of female urinary stress incontinence.

Urologe A. Sep; 43(9):1106-10

14 - CHMEL R., HORCICKA L., VLK R., NOVÁCKOVÁ M. : (2005) Contemporary potential of the mini-invasive surgical treatment of the female stress urinary incontinence.

Cas Lek Cesk.;144(3):155-7.

15 - MARQUÉS QUEIMADELOS A., SOUSA ESCANDÓN A., GARCÍA-FANTINI M., CIMADEVILA GARCÍA A., LEMA GRILLE J. :

(2004) Female urinary stress incontinence: transobturator technique.

Rev Med Univ Navarra. Oct-Dec; 48(4):62-9.

16 - DELORME E. :

(2001)Transobturator urethral suspension: mini-invasive procedure in the treatment of stress urinary incontinence in women.

Prog Urol. Dec; 11(6):1306-13.

17 - DAVILA G.W., JOHNSON J.D., SERELS S. :

(2006)Multicenter experience with the Monarc transobturator sling system to treat stress urinary incontinence.

Int Urogynecol J Pelvic Floor Dysfunct. Sep; 17(5):460-5.

18 - MELlier G., MiSTRANGELO E., GERY L., PHILIPPE C., PATRICE M. : (2007)Tension-free obturator tape (Monarc Subfascial Hammock) in patients with or without associated procedures.

Int Urogynecol J Pelvic Floor Dysfunct. Feb; 18(2):165-72.

19 - LIAPIS A., BAKAS P., CREATSAS G. :

(2008) Monarc vs TVT-O for the treatment of primary stress incontinence: $a$ randomized study.

Int Urogynecol J Pelvic Floor Dysfunct. Feb; 19(2):185-90 
20 - CORTICELli A., CORTICELli G., VENUTI F., PEDRETTI L., DODERO D. : (2005) Preliminary experience with transobturator tape for treatment of urinary incontinence in women.

Minerva Ginecol. Dec; 57(6):637-40

21 - UEBERSAX J.S., WYMAN J.F., SHUMAKER S.A., MCCLISH D.K., FANTL J.A. : (1995) Short forms to assess life quality and symptom distress for urinary incontinence in women: the Incontinence Impact Questionnaire and the Urogenital Distress Inventory.

Continence Program for Women Research Group. Neurourol Urodyn.; 14(2):131-9.

22 - FARNELLI P., CECCARINI M., PARODI A., ROSATI F., STEFANETTI M., VEROCCHI G., CERREONI A. :

(2007). Il management diagnostico della incontinenza urinaria femminile nella pratica clinica.

Riv. Ost. Gin. Med Perin. Vol XXII n. 3/4.

23 - GHONIEM G., STANFORD E., KENTON K., ACHTARI C., GOLDBERG R., MASCARENHAS T., PAREKH M., TAMUSSINO K., TOSSON S., LOSE G., PETRI E. :

(2008) Evaluation and outcome measures in the treatment of female urinary stress incontinence: International Urogynecological Association (IUGA) guidelines for research and clinical practice.

Int Urogynecol J Pelvic Floor Dysfunct. Jan; 19(1):5-33.

24 - DOBSON A., ROBERT M., SWABY C., MURPHY M., BIRCH C., MAINPRIZE T., ROSS S. :

(2007). Transobturator surgery for stress urinary incontinence : 1 year follow up of a cohort of 52 women.

Int. urogynecol. J. 18: 27-32.

25 - DOMingO S., AlAMÀ P., RUIZ N., LABARO G, MORELl M., PELLICCER A. : (2007) Transobturator tape procedure outcome : a clinical and quality of life analysis of 1-year follow up.

Int. Urogynecol. J 18 : 895-900

26 - MELLIER G., BENAYED B., BRETONES S., PASQUIER J.C. :

(2004) Suburethral tape via the obturator route: is the TOT a simplification of the TVT?

Int. Urogynecol J. 227-232. 